\title{
Energy-Efficiency Requirements for Residential Building Envelopes in Cold-Climate Regions
}

\author{
Amy Huynh *, Regina Dias Barkokebas (D), Mohamed Al-Hussein (D), Carlos Cruz-Noguez and Yuxiang Chen (D) \\ Department of Civil and Environmental Engineering, University of Alberta, Edmonton, AB T6G 2R3, Canada; \\ rdbarkokebas@ualberta.ca (R.D.B.); mohameda@ualberta.ca (M.A.-H.); cruznogu@ualberta.ca (C.C.-N.); \\ yuxiang.chen@ualberta.ca (Y.C.) \\ * Correspondence: ahuynh@ualberta.ca
}

check for

updates

Citation: Huynh, A.; Dias

Barkokebas, R.; Al-Hussein, M.;

Cruz-Noguez, C.; Chen, Y.

Energy-Efficiency Requirements for

Residential Building Envelopes in

Cold-Climate Regions. Atmosphere

2021, 12, 405. https://doi.org/

10.3390/atmos12030405

Academic Editors: Meredydd Evans and Michael Donn

Received: 6 March 2021

Accepted: 17 March 2021

Published: 20 March 2021

Publisher's Note: MDPI stays neutral with regard to jurisdictional claims in published maps and institutional affiliations.

Copyright: (c) 2021 by the authors. Licensee MDPI, Basel, Switzerland. This article is an open access article distributed under the terms and conditions of the Creative Commons Attribution (CC BY) license (https:/ / creativecommons.org/licenses/by/ $4.0 /)$.

\begin{abstract}
Due to the energy and environmental impacts attributed to the operational phase of the building sector, efforts have been made to improve building energy performance through the implementation of restrictive energy requirements by regulatory bodies. In this context, the primary objective of this paper is to investigate and compare regulations that govern the building envelope energy performance of new residential buildings in cold-climate regions, primarily in Canada, Finland, Iceland, Norway, Sweden, China, and Russia. The aim is to identify similarities and dissimilarities among the energy regulations of these countries, as well as potentials for development of more effective building codes. This study verifies that the investigated energy requirements diverge considerably-for instance, the required thermal resistance per unit area of above-grade exterior walls in Sweden is almost two times that of a similar climate zone in Canada. Based on the comparisons and case analyses, recommendations for energy requirements pertinent to building envelope of new residential buildings in cold-climate regions are proposed.
\end{abstract}

Keywords: building energy codes; building envelope; housing; residential buildings; cold-climate; energy-efficiency requirements

\section{Introduction}

The building sector accounts for 30-40\% of world primary energy consumption and $20-30 \%$ of greenhouse gas (GHG) emissions [1-3], yet it has potential for energy performance enhancement through the deployment of cost-effective improvements [4-7]. In this context, aiming to reduce the environmental impacts of buildings and boost their energy performance, several approaches have been proposed by governments and third-party organizations, such as implementation of restrictive energy-codes and establishment of voluntary green building rating tools (GBRTs) [8,9]. Leadership in Energy and Environmental Design (LEED) [10], Building Research Establishment Environmental Assessment Method [11], Comprehensive Assessment System for Built Environment Efficiency [12], and the Hong Kong Building Environmental Assessment Method [13] are the most popular GBRTs. These GBRTs have been developed by third-party organizations with the objective of addressing (1) the effects of design choice on the quality of building design, construction and operation; (2) overall building environmental performance; and (3) the integration of buildings with their surroundings [9,14-18]. Since each GBRT has distinct approaches (e.g., evaluation criteria and rating structure), studies have been conducted to compare the approaches applied by GBRTs [17,19-22] and to assess the effectiveness of GBRTs in terms of reducing a building's energy consumption during the occupancy phase [23-27].

However, because GBRT certifications are generally not mandatory unless specified by project mandates or in the design guidelines and policies for a particular jurisdiction (e.g., New York City [28], San Diego [29]), introducing restrictive energy-efficiency requirements in building regulations has been found to be a more effective approach to enhance building energy performance [8,30]. For instance, it is estimated that the energy consumed 
by residential buildings decreased by $10 \%$ to $30 \%$ worldwide in 2016 due to restrictive energy regulations-e.g., in China, improving energy efficiency in households dropped energy consumption by $25 \%$ in 2016 [31]. Indeed, in recent years, several countries have updated their building codes to impose more restrictive energy-efficiency requirements. The Directive on Energy Efficiency in Buildings 2010/31/EU [32] set energy targets for the twenty-eight member states of the European Union (EU-28). According to the 2010/31/EU, by 2020 , the EU-28 is committed to reducing at least $20 \%$ of its energy consumption and GHG emissions compared to 1990 levels, and to increasing the proportion of renewable energy use to $20 \%$ of the overall energy consumed within the same timeframe; this energy package is called the "20-20-20" [33]. According to the European Environment Agency's (EEA) most recent 2019 report, Europe's greenhouse gas emissions and renewable energy development were on track for 2020, but its energy consumption was not, "in terms of both primary and final energy consumption" [34]. The data released between 2014 and 2017 indicates that the final energy consumption had increased every year, and with the current data available, EEA estimates the same trend would follow for 2018 [34].

In the United States, according to the Guiding Principles for Sustainable Federal Buildings $[35,36]$, newly constructed federal buildings are required to have an annual energy use intensity (EUI) (i.e., $\mathrm{kWh} / \mathrm{m}^{2}$ of floor area) at least 30\% lower than that specified in the most recent version of the American Society of Heating, Refrigerating and Air-Conditioning Engineers (ASHRAE) 90.1 Standard, which to date is the ASHRAE 90.1-2019 [37,38]. In addition, the GHG emissions of federal buildings must be reduced by no less than $40 \%$ by 2025, using 2008 as the reference year [39]. For non-federal buildings, the ASHRAE Standard 90.1-2013 [40] is applied to the energy-efficiency of commercial buildings, as well as of residential buildings more than three storeys in height, while the 2012 International Energy Conservation Code (IECC) [41,42] covers residential buildings of three or fewer storeys [42]. In Canada, the Model National Energy Code of Buildings (MNECB) 1997 [43] has been replaced by the National Building Energy Code of Canada for Buildings (NECB) 2011 [44,45], the latter being 25\% more restrictive than the former [30,45,46]. NECB 2011 was then updated again in 2015, to give rise to NECB 2015 [47,48]. Sequentially, NECB 2017 [49] was released and has since been adopted by Saskatchewan, Alberta, and Nova Scotia [44]. This is the latest version of the NECB. The NECB 2017 has an expected improved energy efficiency of approximately 10.3-14.4\%, as compared to the NECB 2011 [50].

Several studies assessing approaches, metrics, and requirements implemented by various jurisdictions to regulate building energy performance have been previously conducted. Rodríguez-Soria et al. [51] concentrated their comparison on the thermal transmittance and air leakage of the building envelope and the indoor temperature of residential buildings in Germany, France, the United Kingdom, Spain, and the USA, while Wong and Krüger [52] compared the Brazilian Energy Efficiency Rating Technical Quality Regulations for Commercial, Service, and Public Buildings to the European Directive 2010/31/EU. Allard et al. [53] investigated methods frequently used to measure the energy performance of residential buildings in Sweden, Norway, and Finland. They found that the metrics and definitions of energy performance applied to residential buildings diverge considerably among these countries. A similar conclusion has been drawn by Annunziata et al. [54], who conducted a survey in 27 Member States of the European Union to verify the current state of national regulatory frameworks.

To date, little research has been focused on investigating and comparing regulations of countries in cold climates such as Canada-with the objective of identifying key practices and potentials for development of more effective building codes. Hence, to fill this gap, this paper, with focus on the envelope of residential buildings in cold-climate regions, aims to (1) assess and compare energy-efficiency requirements, (2) present guidelines relating to the development and implementation of energy-efficiency requirements and effective approaches to code compliance, and (3) recommend requirements and approaches to be incorporated in future editions of building codes, to enhance residential building energy performance. Emphasis is given to building envelope due to the fact that over $50 \%$ of 
buildings energy demand is attributed to heat losses through buildings enclosure [55,56]. This paper focuses on residential buildings, typically houses and low-rise buildings, as a representative. Different buildings offer different types of data, but the elements and approaches are more of less the same. Moreover, the residential building type is selected since two-thirds of the greenhouse gas emissions are accounted by them [57-60], and around $27 \%, 22 \%$, and $17 \%$ of the total energy consumed in the EU-28, the United States, and Canada, respectively, is attributed to the residential building sector [61-63]. For the purpose of the present study, cold climate is defined as a climate between 5000 and 6000 annual Heating Degree-Days (HDDs). HDD is an indicator of how much heating is required in a year. It is the sum of the degree differences between daily average outdoor temperature and a reference temperature (e.g., $18{ }^{\circ} \mathrm{C}$ ) over a year [63]. The climatic conditions of Nordic countries and some regions of Canada, China, and Russia are within this range (Table 1) [40,64-68]. Sweden has a slightly lower HDD $18{ }^{\circ} \mathrm{C}$ of approximately 4517 but is still presented in this paper due to its strict building envelope requirements.

Table 1. Climatic conditions in the jurisdictions under study.

\begin{tabular}{ll}
\hline Thermal Criteria (SI Units) & Jurisdiction \\
\hline & Canada (i.e., Zone 7A) \\
& Iceland (i.e., Reykjavik) \\
$5000<\operatorname{HDD~} 18^{\circ} \mathrm{C} \leq 6000$ & Finland \\
& Norway \\
& Sweden \\
& China (i.e., Harbin) \\
& Russia (i.e., Mezen) \\
\hline
\end{tabular}

\section{Energy-Efficiency Requirements Review}

\subsection{Climate Zone 7A, Canada}

The building codes currently in force in most of the provinces of Canada are the National Building Code (NBC) 2019 and the National Energy Code of Canada for Buildings (NECB) 2017 [69]. The latter focuses on commercial and institutional buildings, and the former covers residential buildings $\leq 600 \mathrm{~m}^{2}$ and $\leq 3$ storeys in height. It is acceptable to use NECB 2017 in lieu of NBC 2019 for any residential building project (as specified by NBC) although it is stated that "it is unlikely that a typical house project will benefit from it" [70].

Both codes (NECB 2017 and NBC 2019) specify energy requirements according to six climate zones, the energy requirements pertinent to this climate zone 7A $(5000 \leq \mathrm{HDD} \leq 5999)$ are analyzed in this study [49,71]. As observed in Table 2, when comparing NECB 2017 with NBC 2019, a number of similarities are identified. These commonalities are expected, since the requirements of each are to complement each other or be somewhat comparable depending on the building type. The Province of Alberta also switched from NECB 2011 to NECB 2017 starting 1 December 2019. While a majority of the thermal resistance requirements, specifically the R-Value Système International (RSI) values $\left(\mathrm{m}^{2} \mathrm{~K} / \mathrm{W}\right)$, have remained the same between the 2011 and 2017 versions, the values for roofs and fenestrations have increased approximately $15 \%$ in both categories. NBC also provides looser restrictions on minimum RSI values if heat recovery ventilator systems (HRVs) are implemented.

In terms of compliance options, both NBC 2019 and NECB 2017 offer three distinct paths: prescriptive, trade-off, and performance. In the prescriptive path, minimum effective RSI values applied to the building envelope, energy efficiency factors (EF) of domestic hot water systems, overall building airtightness, and other construction details are defined. Compliance through this path is achieved if the energy-efficiency requirements are fully met one by one. The trade-off path offers some flexibility in design for above-grade building envelope components (i.e., maintaining the total thermal resistance of the opaque and fenestration parts of the same facade), while the performance path allows for total flexibility in design, provided that the simulated energy consumption of a proposed design is equal to or less than that of a design following the prescriptive requirements of the 
code, which should be proven with an energy simulation software such as CAN-QUEST or HOT2000 $[44,64,72,73]$. Some performance-path investigations were conducted by Dias Ferreira [74], Dias Barkokebas et al. [75], and Hesaraki et al. [76].

Table 2. Comparison of building envelope requirements set by the National Building Energy Code of Canada for Buildings (NECB) 2011, NECB 2017, and National Building Code (NBC) 2019 for climate zone 7A [44,49,71].

\begin{tabular}{|c|c|c|c|c|c|}
\hline \multicolumn{2}{|l|}{ Building Envelope } & \multirow{2}{*}{$\begin{array}{c}\text { NECB } 2011 \\
4.76\end{array}$} & \multirow{2}{*}{$\begin{array}{c}\text { NECB } 2017 \\
4.76\end{array}$} & \multirow{2}{*}{$\begin{array}{c}\text { NBC } 2019 \text { without } \\
\text { HRV } \\
3.08\end{array}$} & \multirow{2}{*}{$\begin{array}{c}\text { NBC } 2019 \text { with } \\
\text { HRV } \\
2.97\end{array}$} \\
\hline \multirow{4}{*}{$\begin{array}{c}\mathrm{RSI}\left(\mathrm{m}^{2} \cdot \mathrm{K} / \mathrm{W}\right) \text { of above-ground } \\
\text { elements }\end{array}$} & Walls & & & & \\
\hline & Roofs & 6.17 & 7.25 & $5.02 / 10.43^{\mathrm{a}}$ & $5.02 / 8.67^{\mathrm{a}}$ \\
\hline & Exposed floors & 6.17 & 6.17 & 5.02 & 5.02 \\
\hline & Fenestrations & 0.45 & 0.53 & $0.63 / 0.37^{b}$ & $0.63 / 0.37^{b}$ \\
\hline \multirow{2}{*}{$\begin{array}{l}\mathrm{RSI}\left(\mathrm{m}^{2} \cdot \mathrm{K} / \mathrm{W}\right) \text { of in-contact with the } \\
\text { ground elements }\end{array}$} & Walls & 3.52 & 3.52 & 3.46 & 2.98 \\
\hline & Floors ${ }^{\mathrm{c}}$ & NA/1.32 & NA/1.32 & $\mathrm{NA} / 2.84$ & $\mathrm{NA} / 2.84$ \\
\hline \multicolumn{2}{|c|}{ Airtightness at 50 Pascal $(\mathrm{Pa})$ pressure difference ${ }^{\mathrm{d}}(\mathrm{ACH})$} & NA & NA & 2.50 & 2.50 \\
\hline
\end{tabular}

${ }^{a}$ Values for cathedral ceiling and flat roof, and ceiling below attic, respectively. ${ }^{b}$ Values for fenestrations and skylights, respectively.

${ }^{c}$ Values for unheated floor below frost line and heated floor, respectively. ${ }^{d}$ The airtightness of the building envelope is not defined for the prescriptive path; prescriptive details are given instead. The value in the table is required for simulating the residential building energy consumption for the performance path. NA: not applicable. ACH: air change per hour; air volume added to or removed from a space in one hour, divided by the volume of the space.

\subsection{Nordic Countries \\ 2.2.1. Finland}

The Finnish building code is one of the most restrictive regulations in Europe in terms of envelope thermal resistance $\left(\mathrm{RSI}, \mathrm{m}^{2} \cdot \mathrm{K} / \mathrm{W}\right)$ requirements $[77,78]$. To date, Section D3 of Finland's National Building Code [79], published in 2013, regulates the energy performance of residential buildings in the country. This code defines the maximum total energy consumption allowed per residential building as a function of its heated area (Table 3) $[79,80]$. The total energy consumption is calculated using an equation given by the Finnish code: It is the sum of various components including heating, cooling, electricity, fuel-use, all normalized by the heated floor area. It also specifies minimum RSI values of building envelope components, building airtightness, and allowable total fenestration area [79]. For single family homes and apartments, if both requirements, building envelope components (See Table 4) and system performance, and heating systems (i.e., energy consumption; see Table 3) are within building code requirements, it is considered compliant with the building code [81]. Researchers have in recent studies verified that, as a result of the updates, the residential building energy consumption in Finland reduced by approximately $5.7 \%$ between 2012 and 2013 [82].

Table 3. Maximum annual energy consumption per area for residential buildings in Finland [79].

\begin{tabular}{|c|c|c|c|c|}
\hline Heated Floor Area $\left(A_{h f}\right)$ & $A_{h f}<120 \mathrm{~m}^{2}$ & $120 \mathrm{~m}^{2} \leq \mathrm{A}_{\mathrm{hf}} \leq 150 \mathrm{~m}^{2}$ & $150 \mathrm{~m}^{2} \leq \mathrm{A}_{\mathrm{hf}} \leq 600 \mathrm{~m}^{2}$ & $A_{h f}>600 \mathrm{~m}^{2}$ \\
\hline $\begin{array}{l}\text { Total energy consumption } \\
\left(\mathrm{kWh} / \mathrm{m}^{2} / \text { year }\right)\end{array}$ & 204 & $372-1.4 \mathrm{~A}_{\mathrm{hf}}$ & $173-0.07 \mathrm{~A}_{\mathrm{hf}}$ & 130 \\
\hline
\end{tabular}

Table 4. Comparison of building envelope requirements for new residential buildings in Finland [79,80].

\begin{tabular}{|c|c|c|c|c|c|c|c|c|}
\hline \multicolumn{2}{|c|}{ Building Envelope } & \multirow{2}{*}{$\begin{array}{c}1976 \\
2.50\end{array}$} & \multirow{2}{*}{$\begin{array}{c}1978 \\
3.45\end{array}$} & \multirow{2}{*}{$\begin{array}{c}1985 \\
3.57\end{array}$} & \multirow{2}{*}{$\begin{array}{c}2003 \\
4.00\end{array}$} & \multirow{2}{*}{$\begin{array}{c}2007 \\
4.17\end{array}$} & \multirow{2}{*}{$\begin{array}{c}2010 \\
5.88\end{array}$} & \multirow{2}{*}{\begin{tabular}{|r|}
2013 \\
5.88
\end{tabular}} \\
\hline RSI-value $\left(\mathrm{m}^{2} \cdot \mathrm{K} / \mathrm{W}\right)$ & Walls & & & & & & & \\
\hline & Roofs & 2.86 & 4.35 & 4.55 & 6.25 & 6.67 & 11.11 & 11.11 \\
\hline & Floors & 2.50 & 2.50 & 2.78 & 4.00 & 4.17 & 6.25 & 11.11 \\
\hline & Windows & 0.48 & 0.48 & 0.48 & 0.71 & 0.71 & 1.00 & 1.00 \\
\hline & Doors & 1.43 & 1.43 & 1.43 & 0.71 & 0.71 & 1.00 & 1.00 \\
\hline & Building element against ground & - & - & - & - & - & - & 6.25 \\
\hline \multicolumn{2}{|c|}{ Total area of glass/doors (\% of heated floor area) } & - & - & - & - & - & - & 50 \\
\hline \multicolumn{2}{|c|}{ Airtightness at 50 Pa pressure difference $\left(\mathrm{L} / \mathrm{s} \cdot \mathrm{m}^{2}\right)$} & - & - & - & - & - & - & 1.11 \\
\hline
\end{tabular}




\subsubsection{Iceland}

The regulation that governs the energy performance of residential buildings in Iceland was published in 2012 [83]. As noted in Table 5, the requirements specified in the Icelandic building code are less ambitious than those in the Finland codes. This is due to the readily available renewable energy resources in Iceland-i.e., $85 \%$ of the primary energy used in the country is from renewable sources (e.g., hydro and geothermal) [84], as well as to the fact that the construction industry has strongly resisted restrictive energy-efficiency requirements in the past [85]. In terms of code compliance, the Icelandic building code determines minimum requirements for the building envelope (Table 5) for new residential buildings. The code specifies building envelope RSI requirements based on the building's interior temperature. Temperatures greater than or equal $15^{\circ} \mathrm{C}$ require higher RSI values as compared to interior temperatures between $5^{\circ} \mathrm{C}$ and $15^{\circ} \mathrm{C}$. This appears to be a natural approach as a smaller temperature difference between the indoors and outdoors will reduce the amount of heat flow through the building envelope. The study focus is on the interior temperatures greater than or equal $15^{\circ} \mathrm{C}$.

Table 5. Building envelope requirements for new residential buildings in Iceland [83].

\begin{tabular}{cccc}
\hline \multicolumn{2}{c}{ Building Envelope } & $\begin{array}{c}\text { Interior Temperature } \\
(\mathbf{T i}) \geq \mathbf{1 5}{ }^{\circ} \mathbf{C}\end{array}$ & $\mathbf{1 5}^{\circ} \mathbf{C}>\mathbf{T i} \geq \mathbf{5}{ }^{\circ} \mathbf{C}$ \\
\hline & Walls & 4.00 & 3.33 \\
RSI-values $\left(\mathrm{m}^{2} \cdot \mathrm{K} / \mathrm{W}\right)$ & Roofs & 6.67 & 4.00 \\
& Floors & 5.00 & 4.00 \\
& Windows & 0.59 & 0.50 \\
Airtightness at 50 Pa pressure difference $\left(\mathrm{L} /\left(\mathrm{s} \mathrm{m}^{2}\right)\right)$ & 0.59 & 0.50 \\
\hline
\end{tabular}

To achieve code compliance, requirements must be fully met. On the other hand, there is no restriction of a maximum energy consumption allowed per heated area in Iceland [83].

\subsubsection{Norway}

The first version of the Norwegian energy regulation went into force in 1986. Since then, a sequence of amendments have updated the original requirements to a stricter level $[85,86]$. To date, the Building Technology Regulations 17 (TEK17, representative of the year 2017) $[87,88]$ regulates the energy performance of residential buildings in Norway. The primary objective of the TEK17 is to loosen (e.g., less restrictive energy requirements) some of the energy requirements set by the TEK10, thereby rendering the energy regulation more achievable and affordable, particularly for residential buildings [88]. In terms of building envelope, the significant changes between these two regulations are related to airtightness, allowed window and door area, and minimum RSI value required for windows and exposed floors, as observed in Tables 6 and 7.

Table 6. Comparison of maximum total annual energy consumption per area for residential buildings in Norway [87-89].

\begin{tabular}{ccccc}
\hline & TEK 97 & TEK07 & TEK10 & TEK17 \\
\hline Energy & & $125+1600 / \mathrm{m}^{2}$ of & $100+1600 / \mathrm{m}^{2}$ of & $100+1600 / \mathrm{m}^{2}$ of \\
consumption & - & heated floor & heated floor & heated floor \\
(kWh/year) & & space $/ 120$ & space $\mid 115$ & space 195 \\
\hline
\end{tabular}

Note: First value accounts for residential buildings with electric space heating and second value is for residential buildings with non-electric space heating. 
Table 7. Comparison of building envelope requirements for new residential buildings in Norway [87-89].

\begin{tabular}{|c|c|c|c|c|c|c|}
\hline Building Envelope & \multirow[t]{2}{*}{ TEK 97} & \multirow[t]{2}{*}{ TEK07 } & \multicolumn{2}{|c|}{ TEK10 } & \multicolumn{2}{|c|}{ TEK17 } \\
\hline & & & $\begin{array}{c}\text { Net } \\
\text { Energy } \\
\text { Demand }\end{array}$ & $\begin{array}{c}\text { Energy } \\
\text { Saving } \\
\text { Measures }\end{array}$ & $\begin{array}{c}\text { Net } \\
\text { Energy } \\
\text { Demand }\end{array}$ & $\begin{array}{c}\text { Energy } \\
\text { Saving } \\
\text { Measures }\end{array}$ \\
\hline \multirow{4}{*}{$\begin{array}{l}\text { RSI-value } \\
\left(\mathrm{m}^{2} \cdot \mathrm{K} / \mathrm{W}\right)\end{array}$} & 4.55 & 5.56 & 4.55 & 5.56 & 4.55 & 5.56 \\
\hline & 6.67 & 7.69 & 6.67 & 7.69 & 5.56 & 7.69 \\
\hline & 6.67 & 6.67 & 5.56 & 6.67 & 5.56 & 10.00 \\
\hline & 0.63 & 0.83 & 0.63 & 0.83 & 0.83 & 1.25 \\
\hline $\begin{array}{l}\text { Heat flux through thermal bridge } \\
\text { normalized by wall area }\left(\mathrm{W} / \mathrm{m}^{2} \cdot \mathrm{K}\right)^{\mathrm{c}}\end{array}$ & - & $\leq 0.03 \mid 0.06$ & NA & $\leq 0.03 \mid 0.06$ & NA & $\leq 0.05 \mid 0.07$ \\
\hline $\begin{array}{l}\text { Airtightness at } 50 \mathrm{~Pa} \text { pressure difference } \\
\qquad(\mathrm{ACH})^{\mathrm{c}}\end{array}$ & - & $\leq 2.5 \mid 1.5$ & $\leq 3.0$ & $\leq 2.5$ & $\leq 1.5$ & $\leq 0.6$ \\
\hline $\begin{array}{l}\text { Total area of glass / doors ( } \% \text { of heated } \\
\text { floor area) }\end{array}$ & 20 & 20 & 20 & 20 & 25 & 25 \\
\hline
\end{tabular}

${ }^{a}$ Value for all outer walls, assume including walls touching ground. ${ }^{b}$ Value for floors on ground and facing open air. ${ }^{\mathrm{c}}$ First value accounts for residential buildings with electric space heating and second value is for residential buildings with non-electric space heating. ACH: air change per hour.

As noted in Table 7, there are two approaches for code compliance in Norway. The Net Energy Demand approach considers simultaneously the total annual energy consumption, which requires the utilization of an energy simulation software and some selected components listed in Table 7 [87]. The other approach, Energy-Savings Measures, does not require an estimation of total annual energy consumption, but aims to ensure a high level of energy performance. Thus its requirements for the building envelope are stricter than those specified in the net energy demand approach.

\subsubsection{Sweden}

In terms of energy-efficiency, Sweden is divided into three zones corresponding to distinct climatic conditions [90]. Zone I refers to the northern area of the country, which has a severe cold-climate condition and, hence, has the most restrictive requirements; zone II covers the central area of the country, and zone III covers the southern region, which has a milder weather and thus the least restrictive requirements [91,92]. According to the Boverket Building Rules (BBR) 19 [93], new residential buildings in Sweden must be designed to ensure it will satisfy the maximum allowed energy use, which is determined according to the given climate zone (Table 8), while its building envelope must have an average thermal resistance equal to or superior to that specified in Table 8. Additionally, the actual residential building energy consumption must be monitored for an entire year, within the first two years following completion of construction; this actual data should be verified against the estimated consumption provided prior to construction [94]. Similar to Norway's regulatory framework, the BBR 19 also offers an alternative approach for compliance [95], which is applicable to residential buildings without cooling systems, with floor area not more than $100 \mathrm{~m}^{2}$ and with a combined area of windows and doors less than $20 \%$ of the heated floor area [93]. For such cases, compliance can be achieved by meeting the energy-efficiency requirements summarized in Table 9.

Table 8. Primary approach to measure the energy performance of new residential buildings in Sweden [93].

\begin{tabular}{cccc}
\hline & Zone I & Zone II & Zone III \\
\hline Total energy consumption $\left(\mathrm{kWh} / \mathrm{m}^{2} / \text { year }\right)^{\text {a }}$ & $95.00 \mid 130.00$ & $75.00 \mid 110.00$ & $55.00 \mid 90.00$ \\
Average thermal transmittance $\left(\mathrm{W} / \mathrm{m}^{2} \cdot \mathrm{K}\right)$ & 0.40 & 0.40 & 0.40 \\
\hline
\end{tabular}

${ }^{a}$ First value accounts for residential buildings with electric space heating, and second value is for residential buildings with non-electric space heating. 
Table 9. Alternative option for code compliance in Sweden [93].

\begin{tabular}{cccc}
\hline \multicolumn{2}{c}{ Building Envelope } & $\begin{array}{c}\text { Residential Building } \\
\text { with Electric Heating }\end{array}$ & $\begin{array}{c}\text { Residential Building } \\
\text { without Electric Heating }\end{array}$ \\
\hline & Walls & 10.00 & 5.56 \\
$\mathrm{RSI}$ value & Roofs & 12.50 & 7.69 \\
$\left(\mathrm{~m}^{2} \cdot \mathrm{K} / \mathrm{W}\right)$ & Floors & 10.00 & 6.67 \\
& Fenestrations & 0.91 & 0.77 \\
Airtightness at 50 Pa pressure difference & $0.61 \mathrm{~L} / \mathrm{s} \cdot \mathrm{m}^{2}$ & $0.61 \mathrm{~L} / \mathrm{s} \cdot \mathrm{m}^{2}$ \\
\hline
\end{tabular}

\subsection{China's Severe Cold Zone}

China's climate is divided up into 5 zones: Severe Cold, Cold, Hot Summer Cold Winter (HSCW), Hot Summer Warm Winter (HSWW), and Temperate [96]. The zone that falls within the HDD criteria is the Severe/Very Cold, with HDD values ranging between about 4000-7000 [97]. The heating energy for northern cities account for $40 \%$ of the total building energy consumption [98]. China's building code for residential buildings in the Severe Cold zone is the JGJ26-2018 “Design Standard for Energy Efficiency of Residential Buildings in Severe Cold and Cold Zones" and was last updated in 2018 [99]. JGJ26-2018 further divides the Severe Cold zone into smaller zones named $1 \mathrm{~A}, 1 \mathrm{~B}$, and $1 \mathrm{C}$ based on HDD $18{ }^{\circ} \mathrm{C}$ values. Zone $1 \mathrm{~B}$ has an HDD $18{ }^{\circ} \mathrm{C}$ value of 5000 to 6000 . China offers both prescriptive and performance-based options for code compliance of the building envelope. The prescriptive path requires that building envelope components RSI must not be less than the values presented in Table 10. There is a general reduction of RSI value requirements for floors $\geq 4$. The performance path requires that the energy consumption (values for both cumulative annual heat load and heating energy consumption are given) of the designed building will not be greater than the reference building listed in the code. The requirements for allowable maximum values $\left(\mathrm{kWh} / \mathrm{m}^{2}\right)$ for cumulative heating load, heating energy consumption, and total energy consumption are defined for each of the 14 cities/districts.

Table 10. Building envelope requirements for residential buildings in China for the Severe Cold climate [100].

\begin{tabular}{|c|c|c|c|}
\hline \multirow{2}{*}{ Building Envelope } & & \multicolumn{2}{|c|}{ Area 1B $(5000 \leq$ HDD18 $<6000)$} \\
\hline & & Floors $\leq 3$ & Floors $\geq 4$ \\
\hline \multirow{4}{*}{$\begin{array}{c}\text { RSI values }\left(\mathrm{m}^{2} \cdot \mathrm{K} / \mathrm{W}\right) \text { of above-ground } \\
\text { elements }\end{array}$} & Walls & 4 & 2.86 \\
\hline & Roofs & 5 & 5 \\
\hline & Floors & 4 & 2.65 \\
\hline & Windows & 0.71 & 0.56 \\
\hline \multirow{4}{*}{$\begin{array}{c}\text { RSI values }\left(\mathrm{m}^{2} \cdot \mathrm{K} / \mathrm{W}\right) \text { of in-contact with the } \\
\text { ground elements } \\
\mathrm{ACH}^{\mathrm{a}}\end{array}$} & Sky Light & 0.71 & 0.63 \\
\hline & Floors & 1.8 & 1.8 \\
\hline & Walls & 2 & 2 \\
\hline & & \multicolumn{2}{|c|}{0.5} \\
\hline
\end{tabular}

a Parameter requirement when calculating heating energy consumption of the proposed building; performance path.

\subsection{Russia}

According to International Energy Agency (IEA) statistics, Russia's building sector was responsible for approximately 33\% of its total secondary energy consumption in 2010, with $80 \%$ of that contributing to space and water heating [101]. The building sector is also Russia's fastest growing energy consumer as its consumption increased from 19\% in 1990 to $33 \%$ in 2010 [101]. Compared to the world average and the US, Russia's energy intensity in the building sector is 1.5 times higher than both, and even double of leading European countries [102].

Russia's building code for energy efficiency was last revised in 2012, namely SP 50.13330.2012 "Thermal Performance of Buildings" and was enforced on 1 July 2013. This was based on the previous 2003 Building Code, SNiP 23-02-2003 “Thermal Protection of 
Buildings". This building code is applicable to residential, public, industrial, agricultural, and warehouse buildings with a total area more than $50 \mathrm{~m}^{2}$ [103]. SP 50.13330 .2012 provides requirements on peak power demand for the heating and ventilation of buildings. Table 11 outlines the peak power demand for low-rise single-family homes, based on predicted values. The required values depend on both building (total floor) area and the number of floors. Tables 11 and 12 reports the values required for apartment buildings, hotels, and hostels which is only dependent on the number of floors. It should be noted that Tables 11 and 12 are not strict requirements as there is a maximum allowable $+15 \%$ deviation from these values. Depending on the amount of deviation, the building is given a Class designation ranging from $\mathrm{A}++$ to $\mathrm{E}$ (10 classes). Only certain classes with good energy performance are allowed for newly erected and reconstructed buildings and eligible for economic incentives. Russia's building code also specifies envelope RSI requirements, with stricter values for areas with higher HDD (colder climates). Values are provided for Russia's various climate zones, ranging in HDD from 2000 to 12,000, by multiples of 2000. Table 13 depicts the 6000 HDD values provided, which is within the intended HDD range of this paper.

Table 11. Peak power demand $\left(\mathrm{W} / \mathrm{m}^{3}{ }^{\circ} \mathrm{C}\right)$ requirements for the heating and ventilation of low-rise single-family buildings in Russia [103].

\begin{tabular}{ccccc}
\hline \multirow{2}{*}{ Total Floor Area $\left(\mathbf{m}^{\mathbf{2}}\right)$} & \multicolumn{4}{c}{ Number of Floors } \\
\cline { 2 - 5 } & $\mathbf{1}$ & $\mathbf{2}$ & $\mathbf{3}$ & $\mathbf{4}$ \\
\hline 50 & 0.579 & $\mathrm{NA}$ & $\mathrm{NA}$ & $\mathrm{NA}$ \\
100 & 0.517 & 0.558 & $\mathrm{NA}$ & NA \\
150 & 0.455 & 0.496 & 0.538 & NA \\
250 & 0.414 & 0.434 & 0.455 & 0.476 \\
400 & 0.372 & 0.372 & 0.393 & 0.414 \\
600 & 0.359 & 0.359 & 0.359 & 0.372 \\
1000 or more & 0.336 & 0.336 & 0.336 & 0.336 \\
\hline
\end{tabular}

Note: Linear interpolation is required between given values.

Table 12. Peak power demand $\left(\mathrm{W} / \mathrm{m}^{3}{ }^{\circ} \mathrm{C}\right)$ requirements for the heating and ventilation of apartment buildings, hotels, and hostels in Russia [103].

\begin{tabular}{ccccccccc}
\hline & \multicolumn{8}{c}{ Number of Floors } \\
\cline { 2 - 9 } & $\mathbf{1}$ & $\mathbf{2}$ & $\mathbf{3}$ & $\mathbf{4 , 5}$ & $\mathbf{6 , 7}$ & $\mathbf{8 , 9}$ & $\mathbf{1 0 , 1 1}$ & $\mathbf{1 2}+$ \\
\hline $\begin{array}{c}\text { Peak Power Demand } \\
\left(\mathrm{W} /\left(\mathrm{m}^{3}{ }^{\circ} \mathrm{C}\right)\right)\end{array}$ & 0.455 & 0.414 & 0.372 & 0.359 & 0.336 & 0.319 & 0.301 & 0.290 \\
\hline
\end{tabular}

Table 13. Building envelope requirements for residential buildings in Russia with annual Heating Degree-Days (HDD) 6000 [103].

\begin{tabular}{cccc}
\hline \multicolumn{2}{c}{ Building Envelope } & SNiP 23-02-2003 & SP 50.13330.2012 \\
\hline & Walls $^{\mathrm{a}}$ & 3.5 & 3.5 \\
& Roofs & 4.6 & 4.6 \\
\multirow{2}{*}{ RSI values $\left(\mathrm{m}^{2} \cdot \mathrm{K} / \mathrm{W}\right)$} & Floors ${ }^{\mathrm{b}}$ & $5.2 / 4.6$ & $5.2 / 4.6$ \\
& Fenestrations & 0.6 & 0.73 \\
& Skylight & 0.4 & 0.4 \\
\hline
\end{tabular}

a Not specified for whether above ground or in-contact with ground, so assumption is that this value is for both. ${ }^{b}$ Value for above ground/in-contact with ground.

New and reconstructed buildings in Russia also require mandatory "energy passports", which shows that the building complies with the code and it allows building officials to monitor energy consumption post-construction. The energy passport should be developed starting at the design phase of the project and should be verified by expert bodies. If there is significant deviation of energy consumption from the original design or 
a lack of technical documentation, the building may be subject to calculative and experimental testing (e.g., testing of structures and facility systems) to confirm compliance again. The energy passport covers both prescriptive and performance measures (simultaneously) for code compliance.

\section{Analyses and Comparison of Building Codes}

The literature reviewed in Section 2 indicates that, aside from the similarities in terms of climatic conditions, significant dissimilarities, regarding the requirements and approaches used to govern the energy performance of building envelope of new residential buildings, exist in the investigated countries. For the purpose of comparing the influences of those dissimilarities in the context of a whole building case (instead of per unit wall or floor area) between the previously outlined jurisdictions, two hypothetical buildings, named $X 1$ and $X 2$, representing large and medium size residential buildings, are used as a basis for analysis. The analysis is focused on the total thermal transmittance of the solid envelope components $U_{\text {envelope }}$ and the thermal transmittance related to air leakage, $U_{\text {air.leakage. }} U_{\text {envelope }}$ accounts for the walls above grade, roof, and windows. Equation (1), below, was applied to these areas and RSI requirements by their respective building code. Tabular results are located in Tables 14 and 15. The Appendix A provides supplementary information (Table A1 for building configurations and Tables A2 and A3 for the thermal transmittance values of each building component of all countries of interest). Equations (2) and (3) were used to calculate the air leakage thermal transmittance, tabular results found in Table A4. Equation (4) shows how the total thermal transmittance calculated in Equation (1) was normalized by the HDD of each country or region in order to show a more representative comparison that considers the range of climatic conditions between the different countries and regions.

$$
U_{\text {envelope }}=\sum_{i} \frac{\text { Area }_{i}}{R S I_{i}}
$$

where $R S I_{i}$ is the minimum required value specified in the building code.

$$
q_{\text {air.leakage }}=\frac{A C H \cdot \text { Area }_{\text {floors }} \cdot \text { room height } \cdot 1000 \mathrm{~L}}{3600 \mathrm{~s}}
$$

where $q_{\text {air.leakage }}$ is the volumetric flow rate in $\left(\frac{L}{s}\right)$. Area $a_{\text {floors }}$ is the floor area.

$$
U_{\text {air.leakage }}=q_{\text {air.leakage }} \cdot \text { specfic heat of air }\left(\frac{\mathrm{kJ}}{\mathrm{kg} \cdot \mathrm{K}}\right) \cdot \operatorname{air} \text { density }\left(\frac{\mathrm{kg}}{\mathrm{m}^{3}}\right)
$$

where $U_{\text {air.leakage }}$ is the thermal transmittance due to the leakage of the building envelope in $\left(\frac{\mathrm{W}}{\mathrm{K}}\right)$.

$$
U_{\text {envelope.normalized }}=\frac{U_{\text {total }}}{H D D} \times 1000
$$

where $U_{\text {envelopenormalized }}$ is the normalized value of $U_{\text {envelope }}$ using the HDD of each country or region, scaled by a factor of 1000 for better visualization in plots.

Building X1 has a total floor area of $600 \mathrm{~m}^{2}$ and 3 storeys in height. As defined by the residential Canadian building code NBC 2019, $600 \mathrm{~m}^{2}$ was chosen as the total floor area as this is the upper limit. The building's floor plan is $10 \mathrm{~m} \times 20 \mathrm{~m}$ with $2.5 \mathrm{~m}$ high walls. To account for fenestrations, four windows were assigned per floor, each with $1 \mathrm{~m} \times 2 \mathrm{~m}$ dimensions. Figures 1 and 2 below show the calculated total thermal transmittance of the envelope, its normalized value, and the thermal transmittance related to air leakage. 


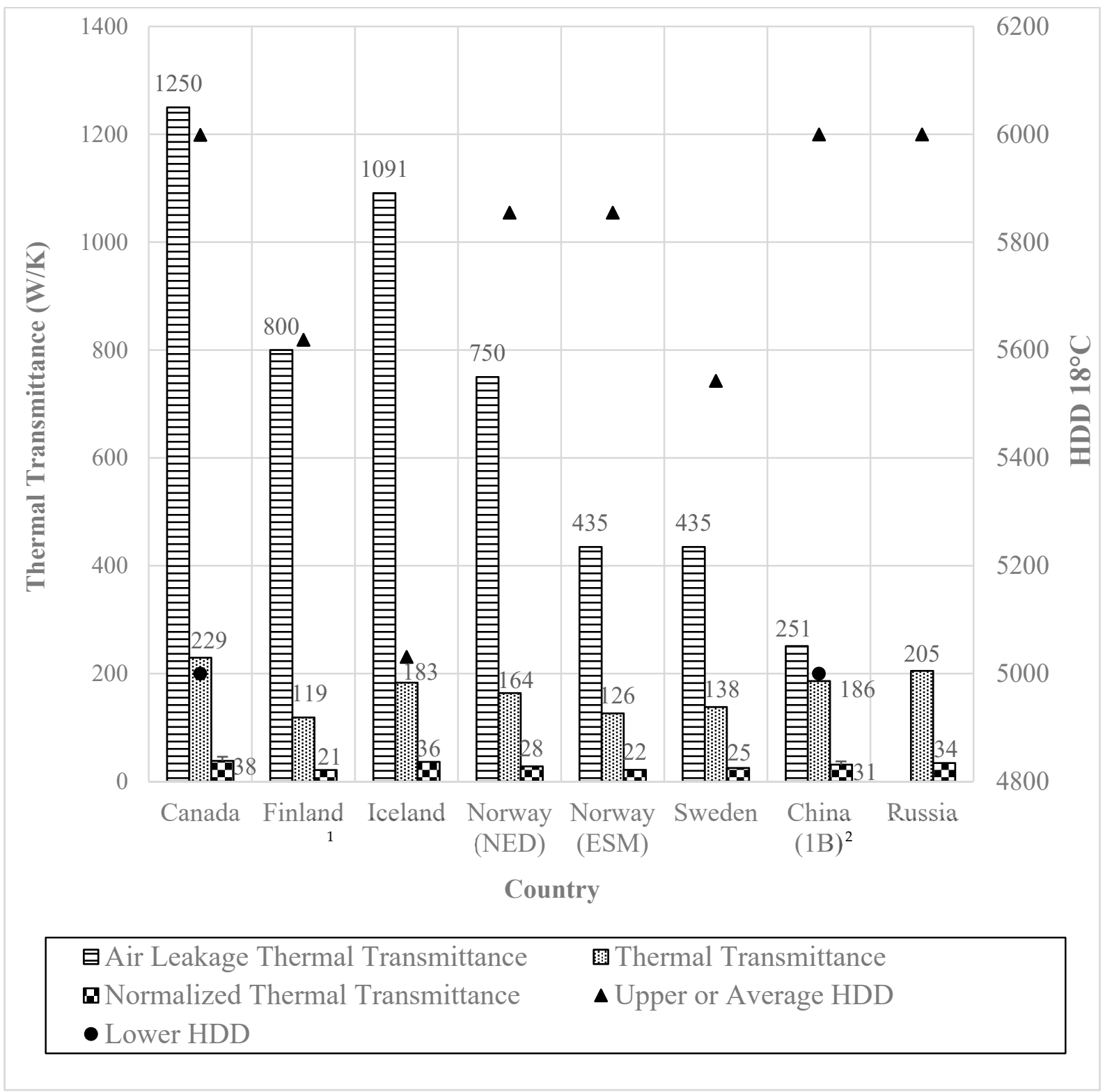

Figure 1. Results of thermal transmittance through Building $\mathrm{X} 1$ of each analyzed jurisdiction. ${ }^{1}$ Requirements specified in Canada's NBC 2019 with heat recovery ventilator (HRV) are applied. ${ }^{2}$ Requirements specified for residential buildings without electric heating (Sweden-W/TEH) are applied.

Table 14. Tabular results of Figure 1. Results of thermal transmittance through Building X1 of each analyzed jurisdiction.

\begin{tabular}{|c|c|c|c|c|c|c|c|c|c|}
\hline & Canada & Finland & Iceland & $\begin{array}{l}\text { Norway } \\
\text { (NED) }\end{array}$ & $\begin{array}{l}\text { Norway } \\
\text { (ESM) }\end{array}$ & $\begin{array}{l}\text { Sweden } \\
\text { (W/TEH) }\end{array}$ & $\begin{array}{l}\text { China } \\
\text { (1A) }\end{array}$ & $\begin{array}{l}\text { China } \\
\text { (1B) }\end{array}$ & Russia \\
\hline Thermal Transmittance $(\mathrm{W} / \mathrm{K})$ & 229 & 119 & 183 & 164 & 126 & 138 & 186 & 205 & 229 \\
\hline $\begin{array}{l}\text { Normalized Thermal } \\
\text { Transmittance }(\mathrm{W} / \mathrm{K})\end{array}$ & 38 & 21 & 36 & 28 & 22 & 25 & 31 & 34 & 38 \\
\hline $\begin{array}{l}\text { Air Leakage Thermal } \\
\text { Transmittance }(\mathrm{W} / \mathrm{K})\end{array}$ & 1250 & 800 & 1091 & 750 & 435 & 435 & 251 & 251 & NA \\
\hline $\begin{array}{c}\text { Normalized Upper Error Bar } \\
\text { Value }(\mathrm{W} / \mathrm{K})\end{array}$ & 8 & NA & NA & NA & NA & NA & 6 & NA & 8 \\
\hline Upper HDD & 5999 & NA & NA & NA & NA & NA & 6000 & NA & 5999 \\
\hline Lower HDD & 5000 & NA & NA & NA & NA & NA & 5000 & NA & 5000 \\
\hline Average HDD & NA & 5619 & 5031 & 5855 & 5855 & 5543 & NA & 6000 & NA \\
\hline
\end{tabular}


Table 15. Tabular results of Figure 3. Results of thermal transmittance through Building X2 of each analyzed jurisdiction.

\begin{tabular}{|c|c|c|c|c|c|c|c|c|}
\hline & Canada & Finland & Iceland & $\begin{array}{l}\text { Norway } \\
\text { (NED) }\end{array}$ & $\begin{array}{l}\text { Norway } \\
\text { (ESM) }\end{array}$ & $\begin{array}{l}\text { Sweden } \\
\text { (W/TEH) }\end{array}$ & $\begin{array}{l}\text { China } \\
\text { (1B) }\end{array}$ & Russia \\
\hline Thermal Transmittance (W/K) & 159 & 84 & 131 & 113 & 86 & 98 & 129 & 140 \\
\hline $\begin{array}{l}\text { Normalized Thermal } \\
\text { Transmittance }(\mathrm{W} / \mathrm{K})\end{array}$ & 27 & 15 & 26 & 19 & 15 & 18 & 21 & 23 \\
\hline $\begin{array}{l}\text { Air Leakage Thermal } \\
\text { Transmittance }(\mathrm{W} / \mathrm{K})\end{array}$ & 625 & 400 & 545 & 378 & 217 & 217 & 126 & NA \\
\hline $\begin{array}{c}\text { Normalized Upper Error Bar } \\
\text { Value }(\mathrm{W} / \mathrm{K})\end{array}$ & 5 & NA & NA & NA & NA & 4 & 62 & NA \\
\hline Upper HDD & 5999 & NA & NA & NA & NA & 7076 & 6000 & NA \\
\hline Lower HDD & 5000 & NA & NA & NA & NA & 4010 & 5000 & NA \\
\hline Average HDD & NA & 5619 & 5031 & 5855 & 5855 & NA & NA & 6000 \\
\hline
\end{tabular}

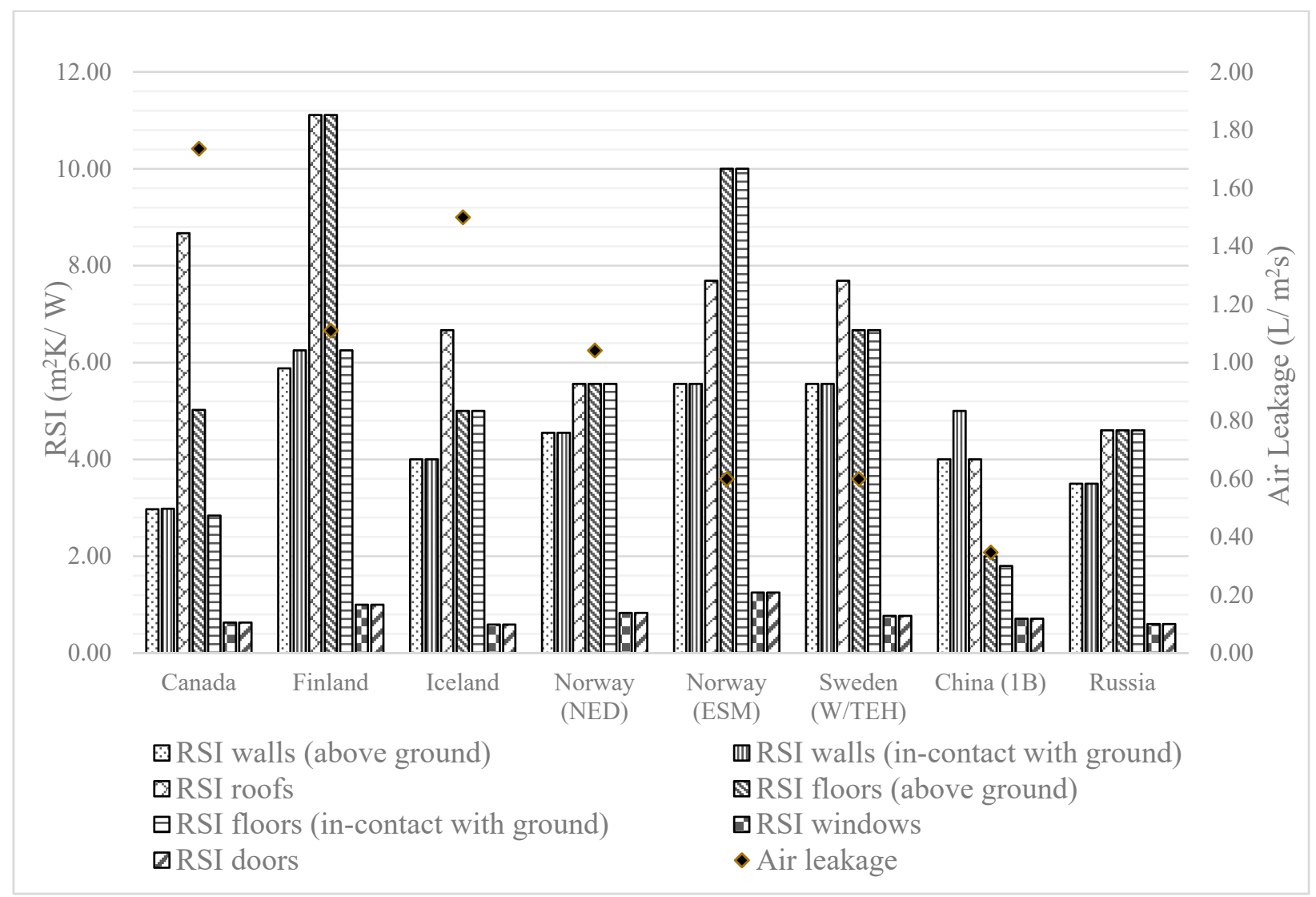

Figure 2. RSI of building envelope components and air leakage specified by analyzed jurisdictions.

As observed in Figure 1, Canada and Finland have the highest and lowest thermal transmittance values through the building envelope, respectively, through Building X1. Both climates are found to have similar HDD values, with Canada (climate zone 7A) ranging between 5000 and 5999 and Finland averaging 5619. Finland's thermal transmittance limits for building envelope components are significantly lower than Canada's, especially with respect to roofs and fenestrations. Canada's results of a high thermal transmittance through the building envelope are due to the fact that Canada specifies the lowest RSI value for exterior walls as noted below in Figure 2. The RSI required by the NBC 2019 is just about $50 \%$ of that specified for residential buildings in Norway (i.e., alternative approach-Norway-ESM) and Finland. In terms of airtightness, which is used as inputs for energy simulations when the performance path chosen as method of compliance, China is found to be the country with the strictest requirements, while Canada is the least strict. 
It should be noted that these are the only two countries in this paper for which values of air leakage are given to use in energy simulations, but not actually enforced.

To account for the different climatic conditions in the analysis of thermal transmittance of building envelope systems, the calculated thermal transmittance is normalized using the HDD of each country or region (e.g., different HDD values for China's $1 \mathrm{~A}$ and 1B regions). Because of the vast size of Canada, Sweden, China, and Russia, their respective building codes further defined building envelope requirements based on region (i.e., HDD ranges). The upper and lower HDD ranges are shown in Figure 1, and the error bars in the normalized thermal transmittance cover the values from the upper to lower HDD. Although Russia does have a range of HDD across its country, it is not shown with error bars because its RSI was defined by a single HDD value, not a range. Values that are between specified values are calculated using an equation, which is an interpolation between the given requirements. Since Sweden's building code does not categorize building envelope requirements based on HDD (i.e., only one set of requirements for all three zones as mentioned in Section 2.2.4), the average HDD of 5543 is used in the normalization [104]. The remaining Nordic countries also did not further specify an HDD range (nor separate zones) within its building code requirements, similar to Sweden, most likely due to a similar climate experienced throughout the respective countries. As observed in Figure 1, after this normalization, Finland has the lowest thermal transmittance, followed closely by Norway (ESM). Thus, relative to its climatic conditions, Sweden has a restrictive regulation to govern its residential building energy performance; contrasting with Canada, which has a less stringent energy regulation when compared to the other investigated countries (e.g., Finland and Sweden).

As an additional comparison, a building with half the floor area of Building X1 (300 m² instead of $600 \mathrm{~m}^{2}$ ), further referred to as Building X2, was used to calculate the building envelope thermal transmittance using the same approach shown in Equation (1) (see Table A1 for configuration details and Table A3 for thermal transmittance calculations for envelope components). The comparison of these two buildings was used to evaluate the impact of building size on thermal transmittance, such as the impact on the air leakage related transmittance. Results are shown below in Figure 3 and Table 15, with calculations in the Appendix A. The reduction in thermal transmittance in both the building envelope and air leakage is due to the overall geometric reduction of the building. The most significant finding of this comparison is that the difference between the air leakage thermal transmittance and building envelope thermal transmittance becomes smaller in Building X2 (e.g., Sweden's building envelope thermal transmittance is 31\% of the air leakage thermal transmittance in Building X1, as compared to $45 \%$ when looking at Building X2). This implies that thermal transmittance with respect to air leakage has a larger influence the larger a building becomes; the weight of the air leakage thermal transmittance becomes much larger in comparison to the building envelope thermal transmittance.

With respect to options for achieving code compliance, as summarized in Table 16, Finland and Russia follow a similar approach that specifies requirements for both thermal resistance and air leakage, alongside a third requirement; Russia defines peak power demand $\left(\mathrm{W} / \mathrm{m}^{3}{ }^{\circ} \mathrm{C}\right)$ for heating and ventilation based on floor area for residential singlefamily buildings and based on number of storeys for other residential buildings (apartments, hotels, hostels) whereas Finland specifies requirements for whole building energy consumption as $\mathrm{kWh} / \mathrm{m}^{2} /$ year (as does Norway and Sweden). Although the Norwegian building energy code offers a similar option for compliance-the net energy demand approach - this option diverges from the one used in Finland and Russia as it specifies different values for thermal resistance and air leakage according to the chosen approach for code compliance. Canada, Iceland, Sweden, and China are similar in that they all establish a prescriptive path in which compliance is considered to have been achieved if the specified parameters for thermal resistance and airtightness are met; however, in Canada, another two paths (i.e., trade-off and performance) for code compliance are offered as well; China and Sweden offer a secondary performance path based on energy consumption. It should 
be noted that Sweden's primary approach is the performance method and the prescriptive method is listed as the alternative option. As mentioned in Section 2, neither Canada or Iceland specifies a maximum annual residential building energy consumption per heated floor area as a requirement and/or option for code compliance. Moreover, only Sweden and Russia require that energy consumption is measured post-construction.

Although Russia's energy intensity is significantly higher than the world average, Russia's normalized thermal transmittance is reasonable in comparison to the other countries in both cases of Building X and Building X2. From this, it is most probable that the jump in energy intensity in Russia is not due to heat loss from the building envelopes, but from other systems.

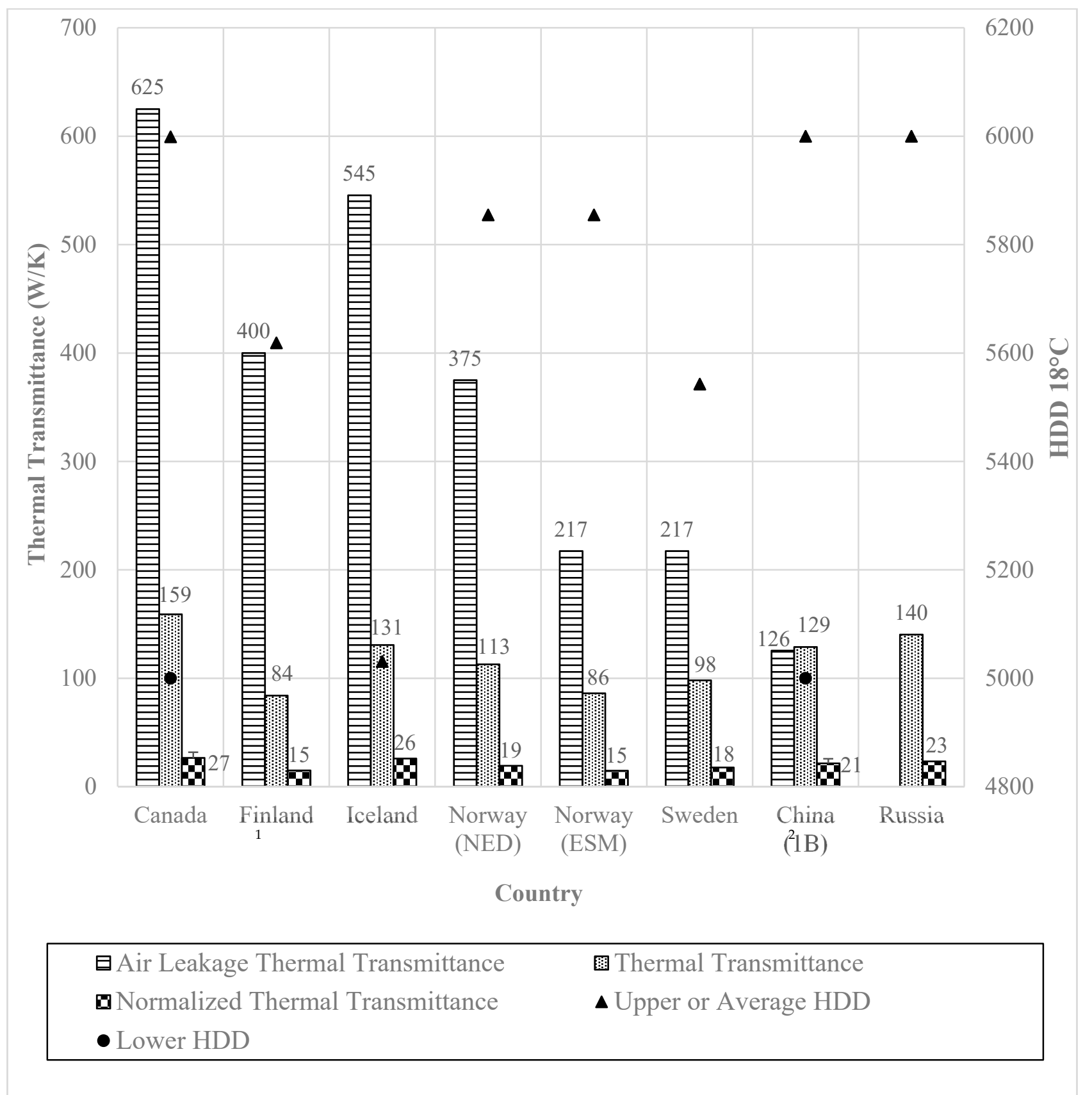

Figure 3. Results of thermal transmittance through Building $X 2$ of each analyzed jurisdiction. ${ }^{1}$ Requirements specified in Canada's NBC 2019 with HRV are applied. ${ }^{2}$ Requirements specified for residential buildings without electric heating (Sweden-W/TEH) are applied. 
Table 16. Comparison of code compliance options set by investigated countries.

\begin{tabular}{|c|c|c|c|c|c|c|}
\hline & $\begin{array}{c}\text { Estimated Energy } \\
\text { Use Intensity } \\
\text { (EUI, kWh } / \mathrm{m}^{2} \text { ) } \\
{[\mathrm{A}]}\end{array}$ & $\begin{array}{c}\text { Prescriptive } \\
\text { Requirements } \\
\text { (e.g., RSI) } \\
\text { [B] }\end{array}$ & $\begin{array}{l}\text { [A] Combined } \\
\text { with [B] } \\
{[C]}\end{array}$ & $\begin{array}{c}\text { Trade-Off Energy } \\
\text { Performance } \\
\text { [D] }\end{array}$ & $\begin{array}{c}\text { Actual Energy } \\
\text { Consumption } \\
{[E]}\end{array}$ & $\begin{array}{c}\text { Peak Power } \\
\text { Demand } \\
\left(\mathrm{W} / \mathrm{m}^{3}{ }^{\circ} \mathrm{C}\right) \\
{[\mathrm{F}]}\end{array}$ \\
\hline Canada & & $x$ & & $x$ & & \\
\hline Finland & & & $X$ & & & \\
\hline Iceland & & $x$ & & & & \\
\hline Norway & & $x$ & $x$ & & & \\
\hline Sweden & $x$ & $X^{a}$ & & & $x$ & \\
\hline China & $x$ & $x$ & & & & \\
\hline Russiab & & $x$ & & & $x$ & $x$ \\
\hline
\end{tabular}

${ }^{a}$ Applicable to residential buildings that are not equipped with cooling systems, whose floor area do not exceed $100 \mathrm{~m}^{2}$, and combined areas of windows and doors account for less than $20 \%$ of the heated floor area [92]. ${ }^{\mathrm{b}}$ Russia requires both prescriptive and performance measures to be met for code compliance.

In terms of recommendations to be incorporated in future residential building energy codes, selecting from the approaches investigated in this study, the introduction of a limited energy use intensity-EUI (i.e., annual energy consumption per heated floor area) as a primary requirement is suggested. The EUI as a requirement or option for code compliance permits design flexibility as long as an energy target, in $\mathrm{kWh} / \mathrm{m}^{2}$ per year, is not exceeded. Although the EUI is not directly related to building envelope specifications, it accounts for actual energy consumed rather than energy demanded (i.e., rate of energy consumedusually measured in $\mathrm{kW}$ ) thus encouraging investments in highly energy-efficient materials and domestic hot water systems as well as innovative design solutions. The performance path options from Canada and China bring these countries closer to this achieving this. Moreover, when combined with other energy requirements as in the case of Norway (i.e., net energy demand approach), it ensures that both power demand and consumption are reduced, thereby improving overall residential building energy performance. EUI has already been adopted by several countries (i.e., column [A] and [C] in Table 16.) Stringent requirements for airtightness and thermal resistance of building envelope components are also suggested to be implemented in future energy building codes, especially in Canada as its requirements are still much less ambitious than many other energy standards under investigation. This discrepancy between the energy-efficiency requirements applied in Canada and the other investigated countries is reflected in the actual energy consumption of residential buildings in these respective jurisdictions.

In addition, the present study recommends that governments and other regulatory institutions release a progression plan/step code for their energy buildings codes. This practice is already present to some extent in Canada, like the BC Energy Step Code, where the energy-efficiency requirements that will eventually become mandatory is first released as a voluntary code compliance paradigm [105]. The definition of a progression plan is an essential step in efforts to streamline communication among stakeholders of the building sector and prepare the market for future changes to the code, given that it anticipates mandatory requirements in forthcoming versions of building codes. With this in place, the development of new construction materials and design solutions, technologies, and systems will be encouraged. Moreover, such a practice stimulates exercises to investigate cost-effective means to achieve code compliance, thereby reducing potential negative impacts on construction practice and attenuating the transition period for newly introduced building energy codes.

Implementing a post-construction energy consumption monitoring system (similar to that of Sweden and Russia), as well as air leakage test, would help to improve energy design practice so that the estimated consumption provided during the design phase can be verified against the actual data. It also holds the manufacturers, construction teams, and engineers accountable to their products and designs. 
The final recommendation is to implement a definitive air leakage requirement, for countries like Canada and China, where values are only given for the building energy simulation when the performance path is chosen as the form of compliance. Seeing that thermal leakage due to air leakage has greater influence the larger a building becomes, having values that are project specific, similar to Russia's building code, would be beneficial in reducing the amount of heat flow lost in larger buildings.

\section{Conclusions}

In this paper, the energy-efficiency requirements that govern the energy performance of building envelope systems in new residential buildings in cold-climate regions, specifically Canada (i.e., Zone 7A), Finland, Iceland, Norway, Sweden, China, and Russia are reviewed, analyzed, and compared. Although the investigated countries feature similar climatic conditions, based on the conducted comparison, it is concluded that there are significant disparities in terms of requirements and options for code compliance among these countries. For instance, the thermal resistance value required for above-grade exterior walls in Canada (with HRV) is just 51\% of that specified in Finland. In terms of similarities, options for code compliance are comparable in Finland, Norway, Sweden, China, and Russia, where the building energy codes establish requirements for maximum annual energy consumption and thermal resistance values (with Finland and Russia requiring both simultaneously and the remaining countries as either/or options).

In light of the findings of this study, guidelines for energy performance requirements are identified, and recommendations for upcoming building regulations, especially in Canada, are proposed as follows: (a) introduction of limited EUI, (b) introduction of stricter RSI values for building envelope, (c) definition of a building code progression plan, (d) introduction of a post-construction energy monitoring system, and (e) introduction of air leakage requirements with HRVs. This study only focuses on the energy performance of building envelope systems, a future direction of research is to extend the comparison to encompass the requirements for domestic systems (e.g., energy efficiency factors of water heating systems and annual fuel utilization efficiency of gas-fired heating systems) as well as energy sources (i.e., promotion of renewable energy use through building codes).

Author Contributions: The paper was written by both A.H. and R.D.B., under the supervision of Y.C., M.A.-H., and C.C.-N. R.D.B. handled the majority of the Nordic country review and Huynh handled the rest. A.H.: Conceptualization, Methodology, Investigation, Writing-Original Draft, Writing-Review \& Editing. R.D.B.: Conceptualization, Methodology, Investigation, WritingOriginal Draft, Validation. Mohammad Al-Hussein: Supervision. C.C.-N.: Supervision. Y.C.: Supervision, Conceptualization, Methodology, Writing-Original Draft, Writing-Review \& Editing. All authors have read and agreed to the published version of the manuscript.

Funding: This research was funded by the Natural Sciences and Engineering Research Council of Canada (NSERC) and the APC was funded by NSERC.

Acknowledgments: This work was supported by the Natural Sciences and Engineering Research Council of Canada (NSERC) and the University of Alberta.

Conflicts of Interest: The authors declare no conflict of interest.

\section{Appendix A}

Table A1. Building dimensions.

\begin{tabular}{ccc}
\hline Building Component & $\begin{array}{c}\text { Building X1 } \\
\text { Total Area }\left(\mathbf{m}^{\mathbf{2}}\right)\end{array}$ & $\begin{array}{c}\text { Building X2 } \\
\text { Total Area }\left(\mathbf{m}^{\mathbf{2}}\right)\end{array}$ \\
\hline Walls above ground & 450 & 300 \\
Roof & 200 & 100 \\
Fenestrations & 24 & 24 \\
\hline
\end{tabular}


Table A2. Building envelope thermal transmittance calculations of Building $X 1$ (W/K).

\begin{tabular}{cccccccccc}
\hline & Canada & Finland & Iceland & $\begin{array}{c}\text { Norway } \\
\text { (NED) }\end{array}$ & $\begin{array}{c}\text { Norway } \\
\text { (ESM) }\end{array}$ & $\begin{array}{c}\text { Sweden } \\
\text { (W/TEH) }\end{array}$ & $\begin{array}{c}\text { China } \\
\text { (1A) }\end{array}$ & $\begin{array}{c}\text { China } \\
\text { (1B) }\end{array}$ & $\begin{array}{c}\text { Russia } \\
\text { Walls above ground }\end{array}$ \\
Roof & 152 & 77 & 150 & 132 & 108 & 108 & 188 & 188 & 171 \\
Fenestrations & 40 & 18 & 30 & 36 & 26 & 26 & 30 & 40 & 43 \\
Total & 38 & 24 & 41 & 29 & 19 & 31 & 34 & 34 & 33 \\
\hline
\end{tabular}

Table A3. Building envelope thermal transmittance calculations of Building X2 (W/K).

\begin{tabular}{cccccccccc}
\hline & Canada & Finland & Iceland & $\begin{array}{c}\text { Norway } \\
\text { (NED) }\end{array}$ & $\begin{array}{c}\text { Norway } \\
\text { (ESM) }\end{array}$ & $\begin{array}{c}\text { Sweden } \\
\text { (W/TEH) }\end{array}$ & $\begin{array}{c}\text { China } \\
\text { (1A) }\end{array}$ & $\begin{array}{c}\text { China } \\
\text { (1B) }\end{array}$ & $\begin{array}{c}\text { Russia } \\
\text { Walls above ground }\end{array}$ \\
Roof & 101 & 51 & 100 & 88 & 72 & 72 & 125 & 125 & 114 \\
Fenestrations & 20 & 9 & 15 & 18 & 13 & 13 & 15 & 20 & 22 \\
Total & 29 & 24 & 41 & 29 & 19 & 31 & 34 & 34 & 33 \\
& 292 & 143 & 236 & 207 & 114 & 176 & 299 & 309 & 248 \\
\hline
\end{tabular}

Table A4. Converting air leakage requirements to RSI value.

\begin{tabular}{|c|c|c|c|c|c|c|c|c|c|}
\hline & Canada & Finland & Iceland & $\begin{array}{c}\text { Norway } \\
\text { (NED) }\end{array}$ & $\begin{array}{c}\text { Norway } \\
\text { (ESM) }\end{array}$ & $\begin{array}{l}\text { Sweden } \\
\text { (W/TEH) }\end{array}$ & $\begin{array}{c}\text { China } \\
\text { (1A) }\end{array}$ & $\begin{array}{c}\text { China } \\
\text { (1B) }\end{array}$ & Russia \\
\hline Air Leakage (ACH) & $2.50^{\mathrm{a}}$ & $\mathrm{N} / \mathrm{A}$ & $\mathrm{N} / \mathrm{A}$ & 1.50 & $\mathrm{~N} / \mathrm{A}$ & $\mathrm{N} / \mathrm{A}$ & $0.50^{\mathrm{a}}$ & $0.50^{\mathrm{a}}$ & $\mathrm{N} / \mathrm{A}$ \\
\hline Air Leakage (1/sm2) & 1.74 & 1.11 & 1.50 & 1.04 & 0.60 & 0.60 & 0.35 & 0.35 & $\mathrm{~N} / \mathrm{A}$ \\
\hline $\begin{array}{l}\text { RSI Air Leakage } \\
\left(\mathrm{m}^{2} \cdot \mathrm{K} / \mathrm{W}\right)\end{array}$ & 0.48 & 0.75 & 0.55 & 0.80 & 1.38 & 1.38 & 2.39 & 2.39 & $\mathrm{~N} / \mathrm{A}$ \\
\hline
\end{tabular}

a Parameter requirement when calculating heating energy consumption of the proposed building; performance path, unlisted otherwise.

\section{References}

1. Dodoo, A.; Gustavsson, L.; Sathre, R. Building energy-efficiency standards in a life cycle primary energy perspective. Energy Build. 2011, 43, 1589-1597. [CrossRef]

2. Ibn-Mohammed, T.; Greenough, R.; Taylor, S.; Ozawa-Meida, L.; Acquaye, A. Operational vs. embodied emissions in buildingsA review of current trends. Energy Build. 2013, 66, 232-245. [CrossRef]

3. Intergovernmental Panel on Climate Change (IPCC). Climate Change 2014: Mitigation of Climate Change; Cambridge University Press: Cambridge, UK, 2014.

4. McKinsey and Company. Reducing US Greenhouse Gas Emissions: How Much at What Cost? U.S. Greenhouse Gas Abatement Mapping Initiative; McKinsey \& Co.: Toronto, ON, Canada, 2007.

5. de T'Serclaes, P. Financing Energy Efficient Homes. Existing Policy Responses to Financial Barries Paris; International Energy Agency: Paris, France, 2007.

6. Galvin, R. Thermal upgrades of existing homes in Germany: The building code, subsidies, and economic efficiency. Energy Build. 2010, 42, 834-844. [CrossRef]

7. Awad, H.; Gul, M.; Zaman, H.; Yu, H.; Alhussein, M. Evaluation of the Thermal and Structural Performance of Potential Energy Efficient Wall Systems for Mid-Rise Wood-Frame Buildings. Constr. Res. Congr. 2014, 82, 416-427. [CrossRef]

8. European Environment Agency. Progress on Energy Efficiency in Europe. Copenhagen, 20 February 2019. 2016. Available online: https:/ / www.eea.europa.eu/data-and-maps/indicators/progress-on-energy-efficiency-in-europe-3 (accessed on 2 March 2020).

9. Chen, X.; Yang, H.; Lu, L. A comprehensive review on passive design approaches in green building rating tools. Renew. Sustain. Energy Rev. 2015, 50, 1425-1436. [CrossRef]

10. U.S. Green Building Council. LEED. Available online: https://new.usgbc.org/leed (accessed on 1 January 2021).

11. Building Group Establishment. BREEAM. Available online: https://www.breeam.com/ (accessed on 6 January 2021).

12. Japan Sustainable Building Consortium. CASBEE. Available online: http://www.ibec.or.jp/CASBEE/english/ (accessed on 6 January 2021).

13. Beam Society Limited. BEAM. Available online: https://www.beamsociety.org.hk/en_index.php (accessed on 2 March 2020).

14. Zuo, J.; Zhao, Z.-Y. Green building research-current status and future agenda: A review. Renew. Sustain. Energy Rev. 2014, 30, 271-281. [CrossRef]

15. Ahmad, T.; Thaheem, M.J.; Anwar, A. Developing a green-building design approach by selective use of systems and techniques. Arch. Eng. Des. Manag. 2016, 12, 29-50. [CrossRef]

16. Bunz, K.R.; Henze, G.P.; Tiller, D.K. Survey of Sustainable Building Design Practices in North America, Europe, and Asia. J. Arch. Eng. 2006, 12, 33-62. [CrossRef] 
17. Illankoon, I.C.S.; Tam, V.W.; Le, K.N.; Shen, L. Key credit criteria among international green building rating tools. J. Clean. Prod. 2017, 164, 209-220. [CrossRef]

18. Cole, R.J. Building environmental assessment methods: Clarifying intentions. Build. Res. Inf. 1999, 27, 230-246. [CrossRef]

19. Haapio, A.; Viitaniemi, P. A critical review of building environmental assessment tools. Environ. Impact Assess. Rev. 2008, 28, 469-482. [CrossRef]

20. Ferreira, J.; Pinheiro, M.D.; De Brito, J. Portuguese sustainable construction assessment tools benchmarked with BREEAM and LEED: An energy analysis. Energy Build. 2014, 69, 451-463. [CrossRef]

21. Forsberg, A.; Von Malmborg, F. Tools for environmental assessment of the built environment. Build. Environ. 2004, 39, 223-228. [CrossRef]

22. Zhang, Y.; Wang, J.; Hu, F.; Wang, Y. Comparison of evaluation standards for green building in China, Britain, United States. Renew. Sustain. Energy Rev. 2017, 68, 262-271. [CrossRef]

23. Alborz, N.; Berardi, U. A post occupancy evaluation framework for LEED certified U.S. higher education residence halls. Procedia Eng. 2015, 118, 19-27. [CrossRef]

24. Bangerth, S.; Ohadi, M.M.; Jenkins, C.A. Energy Analysis of LEED Silver Certified Dining Hall on an Academic Campus-A Revisit Three Years after Its Initial Certification, ASHRAE Transactions; University of Maryland: Park, MD, USA, 2017; Volume 123, pp. 129-139. Available online: http://login.ezproxy.library.ualberta.ca/login?url=http://search.ebscohost.com/login.aspx?direct=true\&db= a9h\&AN=122029284\&site=eds-live\&scope=site (accessed on 2 March 2020).

25. Kern, A.P.; Antoniolli, C.B.; Wander, P.R.; Mancio, M.; González, M.A.S. Energy and Water Consumption during the PostOCCUPANCY Phase and the Users' Perception of a Commercial Building Certified by Leadership in Energy and EnvironMental Design (LEED). J. Clean. Prod. 2016, 133, 826-834. [CrossRef]

26. Zhao, D.; McCoy, A.; Du, J. An Empirical Study on the Energy Consumption in Residential Buildings after Adopting Green Building Standards. Procedia Eng. 2016, 145, 766-773. [CrossRef]

27. Scofield, J.H. Do LEED-certified buildings save energy? Not really. Energy Build. 2009, 41, 1386-1390. [CrossRef]

28. NYC. Design Consultant Guide; Department of Design and Construction: New York, NY, USA, 2015.

29. City of San Diego, Council Policy; San Diego City Council: San Diego, CA, USA, 2010; Policy Number 900-14.

30. Natural Resources Canada (NRCAN). Canada's National Energy Code; Natural Resources Canada (NRCAN): Gatineau, QC, Canada, 2018.

31. International Energy Agency (IEA). Energy Efficiency 2017; International Energy Agency (IEA): Paris, France, 2017.

32. Council of the European Union, and EPBD Recast. Directive 2010/31/EU of the European Parliament and of the Council of 19 May 2010 on the Energy Performance of Buildings. 2010, Volume 18. Available online: https:/ / eur-lex.europa.eu/legal-content/EN/TXT/ ?uri=celex\%3A32010L0031 (accessed on 20 March 2021).

33. European Commission. 2020 Climate E Energy Packages; 2017. Available online: https://eur-lex.europa.eu/summary/EN/ legissum:2001_8 (accessed on 20 March 2021).

34. European Environment Agency. Trends and Projections in Europe, 2019. Tracking Progress towards Europe's Climate and Energy Targets. 15 November 2019. ISSN 1977-8449. Available online: https:/ /www.eea.europa.eu/publications/trends-and-projections-ineurope-1 (accessed on 8 June 2020).

35. U.S. Department of Energy. Guiding Principles; U.S. Department of Energy: Washington, DC, USA, 2017.

36. U.S. Council on Environmental Quality. Guiding Principles for Sustainable Federal Buildings and Associated Instructions. 2016. Available online: https://www4.eere.energy.gov/femp/requirements/guidelines_filtering (accessed on 9 March 2020).

37. American Society of Heating, Refrigerating and Air-Conditioning Engineers (ASHRAE). ANSI/ASHRAE/IES Standard 90.1-2019Energy Standard for Buildings Except Low-Rise Residential Buildings (I-P Edition); American Society of Heating, Refrigerating and Air-Conditioning Engineers, Inc.: Atlanta, GA, USA, 2019.

38. American Society of Heating, Refrigerating and Air-Conditioning Engineers (ASHRAE). ANSI/ASHRAE/IES Standard 90.12016 (I-P)_Energy Standard for Buildings Except Low-Rise Residential Buildings; American Society of Heating, Refrigerating and Air-Conditioning Engineers, Inc.: Atlanta, GA, USA, 2016; p. 96.

39. U.S. Department of Energy. Greenhouse Gas Reduction; U.S. Department of Energy: Washington, DC, USA, 2017.

40. American Society of Heating, Refrigerating and Air-Conditioning Engineers (ASHRAE). ANSI/ASHRAE/IES Standard 90.1-2013 (I-P)_Energy Standard for Buildings Except Low-Rise Residential Buildings. 2013. Available online: https:/ / www.techstreet.com/ ashrae/standards/standard-90-1-2013-user-s-manual?product_id=1878626 (accessed on 20 March 2021).

41. 2012 International Energy Conservation Code (IECC). Available online: https://codes.iccsafe.org/content/IECC2012/toc (accessed on 20 March 2021).

42. U. S. Department of Energy. Building Energy Codes Program: Previous Determinations; U.S. Department of Energy: Washington, DC, USA, 2017; Volume 2017.

43. Canadian Commission on Building and Fire Codes (CCBFC). Model National Energy Code of Canada for Houses; National Research Council of Canada: Ottawa, ON, Canada, 1997.

44. Natural Resources Canada (NRCAN). National Energy Code of Canada for Buildings 2011; 0660200613; N.R.C.O.: Ottawa, ON, Canada, 2011.

45. Model Code Adoption Across Canada. Available online: https://nrc.canada.ca/en/certifications-evaluations-standards/codescanada/model-code-adoption-across-canada (accessed on 20 March 2021). 
46. Adaptation Guidelines for the National Energy Code of Canada for Buildings 2011. Available online: https://nrc.canada.ca/en/ certifications-evaluations-standards/codes-canada/codes-canada-publications/adaptation-guidelines-national-energy-codecanada-buildings-2011 (accessed on 20 March 2021).

47. Norwegian Refugee Council (NRC). National Energy Code of Canada for Buildings; National Research Council: Ottawa, ON, Canada, 2015.

48. Natural Resources Canada (NRCAN). Canada's Energy Code. 2017, Volume 2017. Available online: https://nrc.canada.ca/en/ certifications-evaluations-standards/codes-canada/codes-canada-publications/national-energy-code-canada-buildings-2017 (accessed on 20 March 2021).

49. National Energy Code of Canada for Buildings 2017; 9780660247182; N.R.C.O.: Ottawa, ON, Canada, 2017.

50. Housing Research Summary for 2017. Available online: https://nrc.canada.ca/en/certifications-evaluations-standards / codescanada/codes-canada-publications/housing-research-summary-2017 (accessed on 20 March 2021).

51. Rodríguez-Soria, B.; Domínguez-Hernández, J.; Pérez-Bella, J.M.; Díaz, J.J.D.C. Review of international regulations governing the thermal insulation requirements of residential buildings and the harmonization of envelope energy loss. Renew. Sustain. Energy Rev. 2014, 34, 78-90. [CrossRef]

52. Wong, I.L.; Krüger, E. Comparing energy efficiency labelling systems in the EU and Brazil: Implications, challenges, barriers and opportunities. Energy Policy 2017, 109, 310-323. [CrossRef]

53. Allard, I.; Olofsson, T.; Hassan, O. Methods for energy analysis of residential buildings in Nordic countries. Renew. Sustain. Energy Rev. 2013, 22, 306-318. [CrossRef]

54. Annunziata, E.; Frey, M.; Rizzi, F. Towards nearly zero-energy buildings: The state-of-art of national regulations in Europe. Energy 2013, 57, 125-133. [CrossRef]

55. Fan, Y.; Xia, X. A multi-objective optimization model for energy-efficiency building envelope retrofitting plan with rooftop PV system installation and maintenance. Appl. Energy 2017, 189, 327-335. [CrossRef]

56. Ascione, F.; Bianco, N.; Mauro, G.M.; Napolitano, D.F. Building envelope design: Multi-objective optimization to minimize energy consumption, global cost and thermal discomfort. Application to different Italian climatic zones. Energy 2019, 174, 359-374. [CrossRef]

57. Gaterell, M.; McEvoy, M. The impact of climate change uncertainties on the performance of energy efficiency measures applied to dwellings. Energy Build. 2005, 37, 982-995. [CrossRef]

58. Taylor, P.G.; d'Ortigue, O.L.; Francoeur, M.; Trudeau, N. Final energy use in IEA countries: The role of energy efficiency. Energy Policy 2010, 38, 6463-6474. [CrossRef]

59. Sharma, A.; Saxena, A.; Sethi, M.; Shree, V. Varun Life cycle assessment of buildings: A review. Renew. Sustain. Energy Rev. 2011, 15, 871-875. [CrossRef]

60. European Environment Agency. Final Energy Consumption by Sector and Fuel. 2015. Available online: http://www.eea.europa. eu/data-and-maps/indicators/final-energy-consumption-by-sector-9/assessment (accessed on 13 March 2020).

61. Energy Information Administration (EIA). Energy Consumption by Sector. 2016. Available online: http://www.eia.gov/ totalenergy / data/monthly/pdf/sec2.pdf (accessed on 13 March 2020).

62. Residential Sector-Energy Use Analysis. Available online: https://oee.nrcan.gc.ca/corporate/statistics/neud/dpa/showTable. $\mathrm{cfm}$ ?type $=$ AN\&sector $=$ res\&juris $=00 \& \mathrm{rn}=12 \&$ page $=0$ (accessed on 20 March 2021).

63. University of Winnipeg, Prairie Climate Centre. Heating Degree Days. Available online: https://climateatlas.ca/map/canada/ hdd_2060_85\#lat=55.5\&lng=-90.66 (accessed on 21 February 2021).

64. Natural Resources Canada (NRCAN). Alberta Building Code 2014, 9th ed.; National Research Council of Canada: Ottawa, ON, Canada, 2014.

65. Buildings Performance Institute Europe (BPIE). Europe's Buildings Under the Microscope. A Country-by-Country Review of the Energy Performance of Buildings; Buildings Performance Institute Europe: Brussels, Belgium, 2011.

66. Benestad, R.E. Heating Degre Days, Cooling Degree Days and Precipitation in Europe-Analysis for the CELECT-Project. 2008. Available online: http:/ / met.no/Forskning/Publikasjoner/metno_report/2008/filestore/metno_04-2008.pdf (accessed on 13 March 2020).

67. Ministry of Housing and Urban-Rural Development (MOHURD). Code for Thermal Design of CIVIL Building; Ministry of Housing and Urban-Rural Development (MOHURD): Beijing, China, 2016.

68. State Committee of the Russian Federation for Construction and Housing and Communal Complex, Thermal Protection of Buildings. 2004. Available online: https:/ / runorm.com/catalog/50/784093/ (accessed on 20 March 2021).

69. Govt. of Alberta. Building Codes and Standards. Available online: https://www.alberta.ca/building-codes-and-standards.aspx (accessed on 13 August 2020).

70. NBC(AE)2019:B:9.36 Energy Efficiency Requirement Guide. Available online: https://www.edmonton.ca/residential_ neighbourhoods/documents/PDF/NBC_AE_9.36_Energy_Efficiency_Requirements_Guide.pdf (accessed on 20 March 2021).

71. National Building Code-2019. Available online: https://nrc.canada.ca/en/certifications-evaluations-standards/codes-canada/ codes-canada-publications/national-building-code-2019-alberta-edition-nbcae (accessed on 20 March 2021).

72. Energy Management Software for New Buildings. Available online: https://www.nrcan.gc.ca/energy-efficiency/energyefficiency-buildings/energy-management-resources-buil/energy-management-software-new-buildings/22468 (accessed on 20 March 2021). 
73. HOT2000 Software Suite. Available online: https://www.nrcan.gc.ca/energy-efficiency/energy-efficiency-homes/professionalopportunities/tools-industry-professionals/20596 (accessed on 20 March 2021).

74. Ferreira, R.D. Least-Construction-Cost Approaches for New Housing to Achieve Higher Energy-Efficiency Requirements of Building Codes. 2017. Available online: http:/ /hdl.handle.net/10402/era.43664 (accessed on 13 August 2020).

75. Barkokebas, R.D.; Chen, Y.; Yu, H.; Al-Hussein, M. Achieving housing energy-efficiency requirements: Methodologies and impacts on housing construction cost and energy performance. J. Build. Eng. 2019, 26, 100874. [CrossRef]

76. Hesaraki, B.; Chen, Y.; Ferreira, R.D.; Al-Hussein, M. Energy code compliant house design for lowest lifecycle cost based on market-available technologies. Can. J. Civ. Eng. 2019, 46, 308-321. [CrossRef]

77. Haakana, M.; Laitila, P. Implementation of the EPBD in Finland. Status at the end of 2012, Volume 1, (Implementing the Energy Performance of Buildings Directive (EPBD). Featuring Country Reports 2012. Porto: Concerted Action EPBD. 2013, pp. 173-180. Available online: https://www.buildup.eu/en/practices/publications/implementing-energy-performance-buildings-directiveepbd-featuring-country-0 (accessed on 20 March 2021).

78. Finnish Ministry of the Environment. Ministry of the Environment Decree on Improving the Energy Performance of Buildings Undergoing Renovation or Alteration Explanatory Memorandum; Ministry of the Environment: Helsinki, Finland, 2013.

79. Finnish Ministry of the Environment. National Building Code of Finland 2/11; Ministry of Environment: Helsinki, Finland, 2013.

80. Global Buildings Performance Network (GBPN). Database \& Tools—Finland; 2016. Available online: https://joinup.ec.europa.eu/ sites/default/files/inline-files/eGovernmnent\%20in\%20Finland\%20-\%20February\%202016\%20-\%2018_00\%20-\%20v2_00.pdf (accessed on 20 March 2021).

81. Haakana, P.L.M.; Forssell, K.-M. Implementation of the EPBD in Finland. Concerted Action-Energy Performance of Buildings. Available online: https:/ / www.buildup.eu/en/practices / publications/implementation-epbd-finland-status-november-2010 (accessed on 18 August 2020).

82. Govt. of Finland. Annual Report on the EDD 2015. Report to the European Commission pursuant to Article 24(1) of the Energy Efficiency Directive. 2015. Available online: https://ec.europa.eu/energy/sites/ener/files/documents/FI_AnnualReport2015_ en.pdf (accessed on 18 August 2020).

83. Ministry of Justice. Icelandic Building Regulations; Ministry of Justice: London, UK, 2012.

84. National Energy Authority. Iceland-A Leader in the Use of Renewable Resources, Reykjavík. 2017. Available online: http: / / os.is/gogn/Frettir/Iceland_Leader_RenewableEnergy.pdf (accessed on 21 August 2020).

85. Sand, H.; Lorenzen, K.H.; Nittegaard, C.B. Survey of Green Legislation and Standards in the Construction Area in the Nordic Countries, Copenhagen. 2012. Available online: http:/ / www.nordicinnovation.org/publications (accessed on 21 August 2020).

86. Energy Efficiency Trends and Policies in Norway. Available online: https://ife.brage.unit.no/ife-xmlui/bitstream/handle/1125 0/2598309/IFE-KR-E-2015-003.pdf?sequence=1\&isAllowed=y (accessed on 20 March 2021).

87. Norwegian Building Authority, Regulations on Technical Requirements for Construction Works. 2017. Available online: https:// dibk.no/globalassets/byggeregler/regulation-on-technical-requirements-for-construction-works--technical-regulations.pdf (accessed on 20 March 2021).

88. Building Technology Regulations (TEK17). Available online: https:/ / dibk.no/globalassets/byggeregler/regulation-on-technicalrequirements-for-construction-works--technical-regulations.pdf (accessed on 20 March 2021).

89. Building Technology Regulations (TEK10). Available online: https://dibk.no/globalassets/byggeregler/regulations_on_ technical_requirements_for_building_works.pdf (accessed on 20 March 2021).

90. Laustsen, J. Energy Efficiency Requirements in Building Codes, Energy Efficiency Policies for New Buildings. 2008. Available online: https: / /www.iea.org/publications/freepublications/publication/Building_Codes.pdf (accessed on 4 September 2020).

91. Implementation of the EPBD in Sweden. Status in November 2010. Available online: https:/ / epbd-ca.eu/ca-outcomes/outcomes2015-2018/book-2018/countries/sweden (accessed on 20 March 2021).

92. Dodoo, A.; Gustavsson, L. Effect of Energy Efficiency Requirements for Residential Buildings in Sweden on Lifecycle Primary Energy Use. Energy Procedia 2014, 61, 1183-1186. [CrossRef]

93. Boverket's Building Regulation (BBR) 19. Available online: https://www.boverket.se/sv/lag--ratt/forfattningssamling/ gallande/bbr---bfs-20116/ (accessed on 20 March 2021).

94. Swedish Building Regulations, P. Group. 2017. Available online: http://www.paroc.se/knowhow/building-regulations/ swedish-building-regulations?sc_lang=en (accessed on 4 September 2020).

95. Energy Efficiency of New Residential Buildings in Sweden. Available online: https://www.researchgate.net/publication/273038 264_Energy_efficiency_of_new_residential_buildings_in_sweden_Design_and_Modelling_Aspects (accessed on 20 March 2021).

96. Bin, L.J.S. Building Energy Efficiency Policies in China. 2012. Available online: https://www.aceee.org/research-report/e129 (accessed on 3 October 2020).

97. Zhang, Q. Climatic Zoning for the Thermal Design of Residences in China Based on Heating Degree-Days and Cooling De-greeHours. J. Asian Archit. Build. Eng. 2005, 4, 533-539. [CrossRef]

98. Lu, Z.W.S.; Zhang, T. Quantitative analysis and multi-index evaluation of the green building envelope performance in the cold area of China. Sustainability 2020, 12, 437. [CrossRef]

99. Yu, W.X.Z.; Chen, X.; Sun, D.; Zhang, J.; Lu, F.; Liu, C. Progress in Energy Efficiency Standards of Residential Buildings in China's Severe Cold and Cold Zones, Presented at the E3S Web of Conferences 111, 03032 (2019); CLIMA: Bucharest, Romania, 2019. 
100. JGJ 26-2018, MOHURD. 2018. Available online: http:/ / www.codeofchina.com/standard/JGJ26-2018.html (accessed on 20 March 2021).

101. Zhitenko, Y.S.T.; Saussay, A.; Levina, E.; Murray, I. How to make efficient buildings a reality in Russia? In Proceedings of the the ECEEE Summer Study Proceedings, Hyères, France, 3-8 June 2013.

102. Henderson, T.M.J. Implications of the Global Energy Transition on Russia; Springer: Cham, Switzerland, 2020.

103. Research Institute of Building Physics of the Russian Academy of Architecture and Building Sciences. SP 50.13330.2012 Thermal protection of buildings; Ministry of Regional Development of Russia: Moscow, Russia, 2013.

104. Eurima. ECOFYS: U-Values for Better Energy Performance of Buildings, Annex 1, ed. 2007. Available online: https://www. eurima.org/uploads/F_EURIMA-ECOFYS_VII_report_p1-65.pdf (accessed on 20 March 2021).

105. Building and Safety Standards Branch of the Govt. of British Columbia. How the BC Energy Step Code Works. Available online: https: / / energystepcode.ca/how-it-works / (accessed on 29 December 2020). 